\title{
Characterization of Sealing Materials by Energy Dispersive $X$-ray Spectrometry and Scanning Electron Microscopy
}

\begin{abstract}
CATALINA IULIA SAVEANU ${ }^{1}$, OANA DRAGOS², ADINA ARMENCIA*, IRINA BAMBOI' ${ }^{1}$, ALEXANDRA ECATERINA SAVEANU1, OANA TANCULESCU ${ }^{1}$

${ }^{1}$ University of Medicine and Pharmacy Grigore T.Popa, Faculty of Dental Medicine, 16 Universitatii Str., 700115, Iasi, Romania

${ }^{2}$ National Institute of Research-Development for Technical Physics - IFT Iasi, 47 Dimitrie Mangeron, 700050, Iasi, Romania

Disadvantages of diacrilic composite resins and glass ionomers cements have stimulated research to develop hybrid materials to eliminate the downsides and take advantage of their benefits. The purpose of this study was comparative analysis of a resin composite and hybrid materials compomers sealing material used in preventive sealing by Energy Dispersive X-ray Spectrometry and Scanning Electron Microscopy (SEM).
\end{abstract}

Keywords: composite, compomer, microleakage, sealant, prevention

The sealing materials presently present have important characteristics regarding rheology, adhesiveness, sealing capacity, wear resistance, polish ability. The main objective in the practical approach of the sealing materials is the sealing of the retentive dental surfaces, respectively of the occlusal faces of the molars and premolars, the vestibular pits of the lower molars and oral of the upper molars, as well as the Foramina Caeca pits. The quality of the sealing depends on the clinical conditions of accomplishment, on the compliance with the manufacturer's instructions. The orientation towards one material or another of sealing is done according to the topography of the surface, the characteristics of the enamel substrate, the patient's occlusion, the individual caries risk, the degree of filler of the material, the viscosity of the material to favor the penetrability in the micro retention of the acid etched enamel, but not lastly of the possibility of the material to exert a caries inhibitory effect by releasing fluorine. Dyract Seal - Compomer pit and fissure sealant for the Total-Seal ${ }^{\mathrm{TM}}$ technique. With NRC ${ }^{\text {TM }}$ Non-Rinse Conditioner, DENTSPLY has introduced an innovative acid conditioning procedure for Dyract ${ }^{\circledR}$ compomer materials. NRC is applied for 20 seconds to the surface to be conditioned. Afterwards, remaining material is removed with the air spray. Sealing without rinsing enhances acceptance of the treatment procedure particularly atchildren. Also the compomer and it combines total sealing ability, high abrasion resistance, excellent mechanical properties, and long-term fluoride release. So, the null hypothesis of this study was that there are no differences in the in vitro behavior of these materials. The testable hypothesis is there are differences in the in vitro behavior of these materials. Thus, the purpose of this study was the comparative analysis of two types of sealing materials, by EDS evaluation, their composition, the filler loading degree, the interaction with enamel by SEM evaluation.

\section{Experimental part}

Sample preparation - Since the electron probe analyses only to a shallow depth, specimens were well polished so that surface roughness does not affect the results. For transmitted light viewing, polished thin sections on glass slides are prepared. 1.

The components of the materials used are listed in Table

The microstructure was analyzed by SEM (Scanning Electron Microscopy - JEOLJ SM 6390a J apan). The materials were applied in conformity with manufacturer indication between two matrix strips of celluloid (Nr. 437 Alfred Becht GmbH-D 7600 Offenburg, Germany) and then between two glasses plates to obtain a flat surface. We used a conventional quart halogen lamp (QTH), power density $570 \mathrm{~mW} / \mathrm{cm}^{2}$ (3MESPE). The analyze of the material was realized in surfaces for each side of each tooth.

\section{Results and discussions}

The EDS analysis of the sealing materials (Fig.1A, 1B) revealed at the level of the Dyract Seal (Dentsply DeTrey) sealing material the presence of the following materials $\mathrm{C}(45.66 \%), \mathrm{O}(23.93 \%), \mathrm{F}(4.3 \%), \mathrm{Na}(1.11 \%) \mathrm{Al}(8.63 \%)$ Si $(9.49 \%) \mathrm{Au}(6.88 \%)$. EDS analysis of the Helioseal sealing material (Ivoclar Vivadent) highlighted the presence C (41.71\%), O (27.49\%), Na (1.06\%), Al (3.11\%), Si (16.55\%) si a $\mathrm{Ca}(1.51 \%) \mathrm{Au}(8,57 \%)$ (Fig.2).

\begin{tabular}{|l|l|l|}
\hline Sealeant & \multicolumn{1}{|c|}{ Composition } & Manufacturer \\
\hline Dyract seal & $\begin{array}{l}\text { M-1A-BSA, aminopenta initiator system, strontiumaluminium- } \\
\text { fluorosilicate glass }\end{array}$ & DentsplyDeTrey \\
\hline Helioseal & $\begin{array}{l}\text { Bis-GMA, triethylene glycol dimethacrylate }(<97 \mathrm{wt} \%), \text { titanium } \\
\text { dioxide }(2 \mathrm{wt} \%), \text { stabilizers and catalysts }(<1 \mathrm{w} \%) .\end{array}$ & Ivoclar Vivadent \\
&
\end{tabular}

Table 1

THE CHEMICAL PRINCIPLES OF THE MATERIALS USED IN THE STUDY

*email: oanaarmencia@yahoo.com 


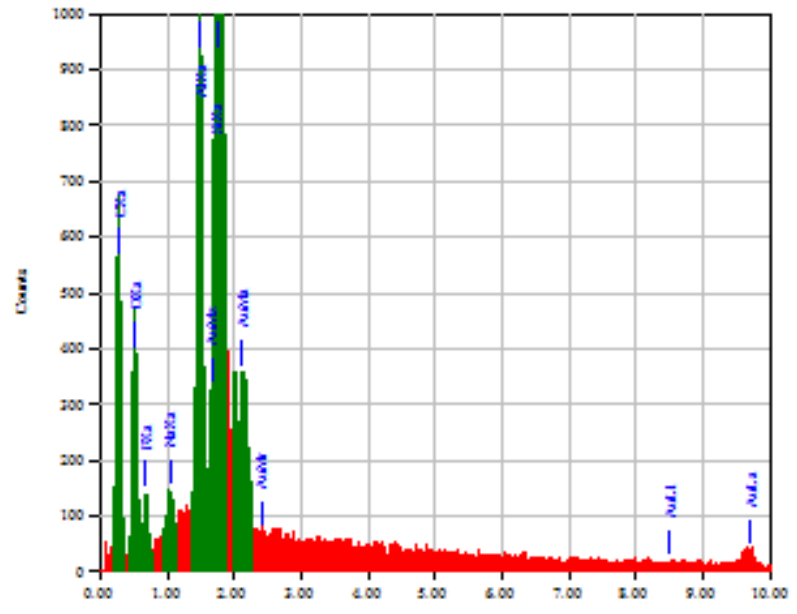

Fig. 1. EDS analysis of sealing material - Dyract Seal (Dentsply DeTrey)

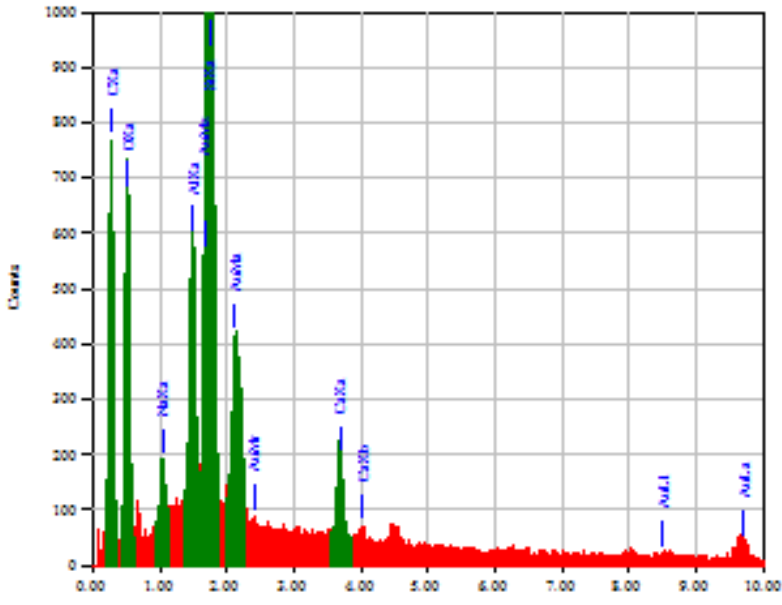

Fig. 2.EDS analysis of sealing material B - Helioseal (Ivoclar Vivadent)

Also, the microstructure showed a filler loading more accentuated to the compomer material. This thing is in favor of wear resistance and disintegration over time (Fig. 2, 3)

The higher filler weight, increase wear-resistant for surface, and the lower filler weight it is in favor for smoother surface so will not favor bacterial plaque adhesion (Fig.3,4).

Scanning electron microscope (SEM) produces images of a sample by scanning the surface and can achieve resolution better than 1 nanometer. Characteristic X-ray that are produced by the interaction of electrons with the sample mayalso be detected in an SEM equipped for energydispersive X-ray spectroscopy (EDS) or wavelength dispersive X-ray spectroscopy.

The main sealing materials used in practice are glass ionomer cements, hybrid restorative materials and composite resins. The difference in viscosity of the materials is given by the degree of re-filling of the material, by its filler content. The materials with the lowest viscosity and which favor a good wettability of the substrate are those withoutfiller. But filler-free materials do not withstand wear over time. Achieving the main objective of sealing the dental retentive surfaces depends on the possibility of micromechanical interlocking at the enamel level. In these aspects, the composite resins have a very good wear resistance and very good intricacy of the material in the dental infrastructure with a less cariostatic effect than of the other materials, being present only with certain fluoride sealants. Compomers are composite materials in $75 \%$ by weight mixed with $25 \%$ glass ionomer. Thus, these
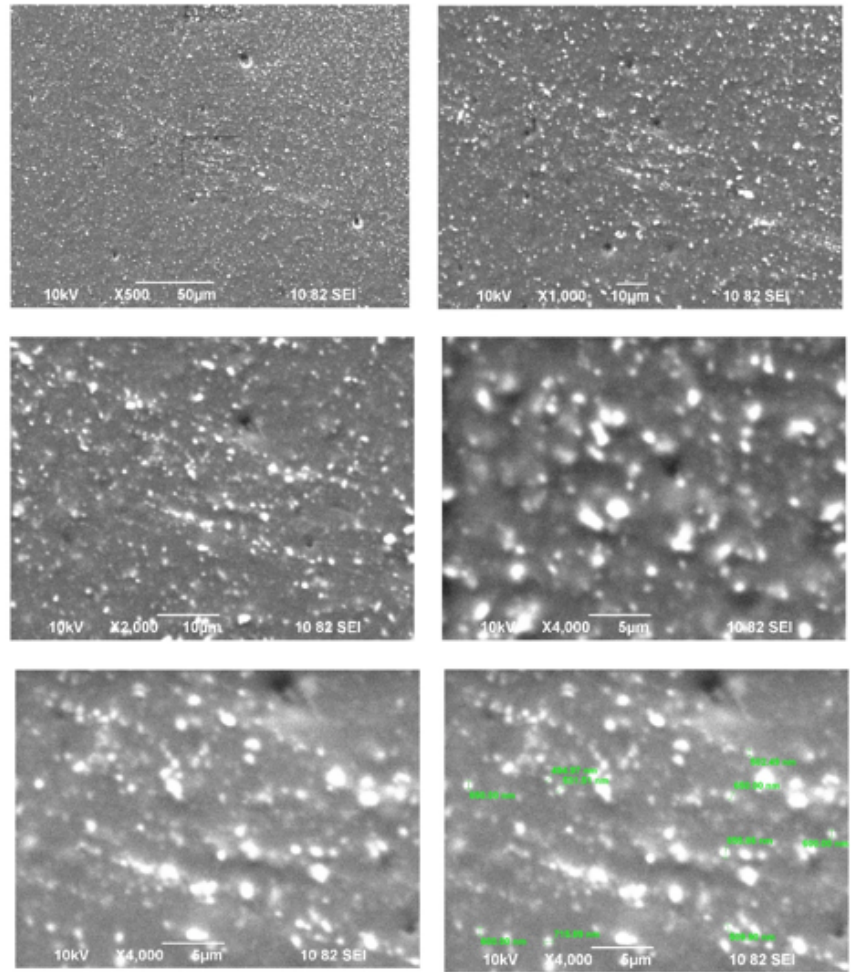

Fig. 3. Top view- from Dyract Seal structure of the material at the magnification of X500, X1000, X2000, X4000
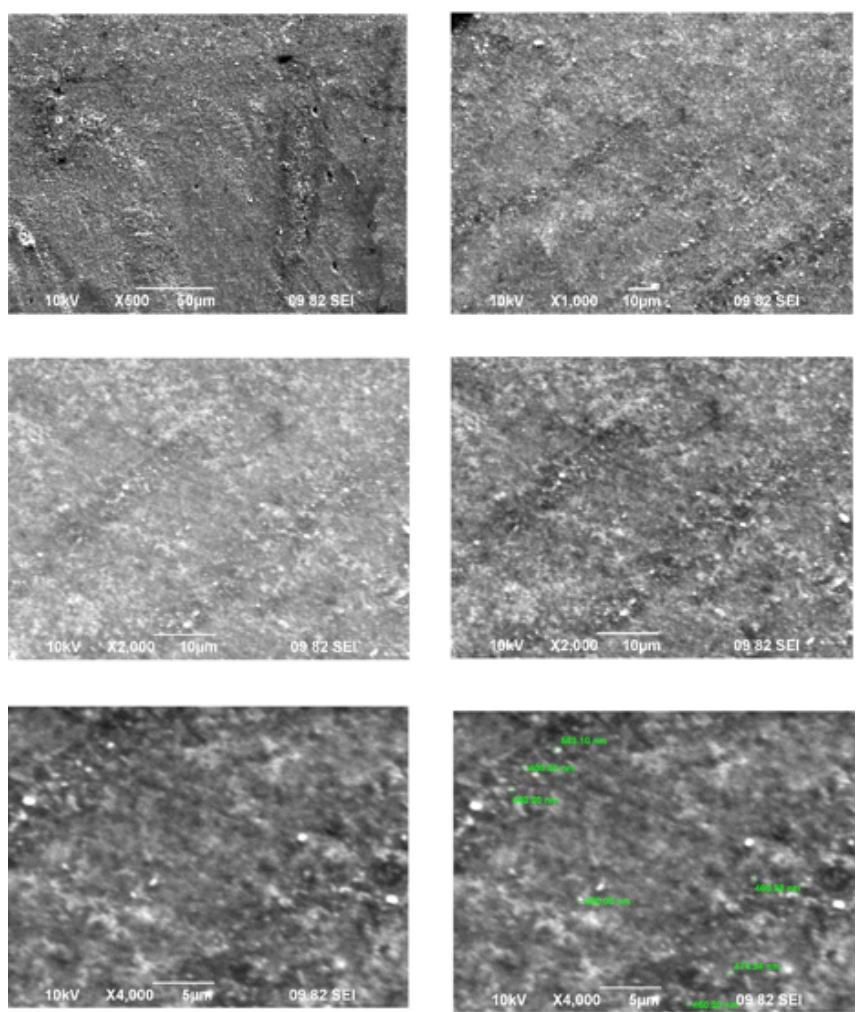

Fig. 4. Top view- from Helioseal structure of the material at the magnification of X500, X1000, X2000, X4000

materials have all the advantages of composites and in addition the release of fluoride with inhibitory caries effect. The clinical approach to these issues is in the context of non-compliance with a dry operating field the adhesion power of the restoration materials can be reduced from $20 \%$ to $100 \%$. Helioseal is a light-curing, white-shaded fissure sealant. The white-shaded sealant permits easy control during application and at recalls, optimum flow properties, easy to check retention. Hence, Dyract Seal compomer material has two curing reactions photoinitiated polymerisation and acid-base reaction which is the basis 
of the continuous release of fluoride ions strontiumaluminium-fluorosilicate glass initial $2.0 \mu \mathrm{g} / \mathrm{cm}^{2}$, and after constant fluoride release $1.4 \mu \mathrm{g} / \mathrm{cm}^{2}$. Dyract Seal has radiopacity as high as that of enamel ( $2 \mathrm{~mm} \mathrm{Al}$ ). Six other fissure sealants were examined and though some of the materials showed a higher initial fluoride release than Dyract Seal, this release decreased below the level of Dyract Seal within 5 weeks. After 10 weeks the fluoride release of Helioseal and Fissurit $F$ was almost below detection level. Also Dyract Seal has a significantly higher wear resistance than conventional fissure sealants such as Concise or Delton Plus (De Gee et al., 1994) [1-4]. A study realized for 24-month on a polyacid-modified resin composite Dyract Seal and Delton Seal show that there were no statistically significant differences as regards to retention of sealant and prevention of caries for all period of the evaluation. However, regarding marginal integrity of the sealants, Delton FS+ gave significantly better results than Dyract Seal [5]. For anoher study where four commercial pit and fissure sealants have been studied in respect of water absorption and solubility Fotoseal (R) (Babes-Bolyai University, Raluca Ripan Chemistry Research Institute), Fissurit FX (R) (VoCo), one gass-ionomer - Fuji Triage (R) (GC Fuji) and one compomer - Dyract Seal (R) (Dentsply) showed that Fissurit FX had the lowest values of water sorption and solubility, closely followed by Fotoseal and Dyract Seal with Fuji Triage had higher values [6]. Another study with Dyract Seal which evaluated antibacterial properties show that this effect is presentafter a daily 30 second rinse for two weeks with a $0.05 \% \mathrm{NaF}$ solution [7]. An study which compare the the interface between enamel surfaces at the level of pit and fissure and the sealant with different cleaning procedures, with or without acid etching show that Concise White Sealant achieves a better enamel sealing than Dyract Seal when the teeth are treated with air abrasion or air polishing followed by etching [8]. The microhydrid composite resins have a significantly higher hardness than nano-hybrid composites or compomers $[9,10]$ and in another study on top and on bottom surfaces DyracteXtra showed the lowest hardness values [11]. Beresescu and all considered that particular types of restoring materials should be used in particular situation, depending on the location of the surfaces and the elastic characteristics of the materials and tooth structure [12]. Sealing is a method that can prevent tooth decay. But this method is especially recommended in patients at risk of caries. In the conditions in which the mother presents a high caries risk often highlighted in many specialized studies $[13,14]$ and evaluated according to criteria for establishing it, this method is highly recommended. Prevention is aimed at all age groups, but the numerous studies on geriatric patients orally rehabilitated complex orient us tow ards the indication and application of these materials as early as possible [15].

\section{Conclusions}

In the limit of this study we can concluded that there is a difference between composite and compomer sealant used in primary and secondary prevention but each material is good if the indication for his utilization is correct.
Many clinical study are necessary for tested the materials in time. Fluoride reloading of the material is definitely a clinical advantage. The fact that in clinical use the compomer sealant does not require washing after applying non-acid rinse, reduces working time and thus reduces the possibility of salivary contamination.

\section{References}

1.CROLL TP (1996). The quintessential sealant?. Quintessence Int 27:11;729-732.

2.DE GEE AJ, PALLAV P (1994). Occlusal wear simulation with the ACTA wear machine. J Dent Suppl. 1, 22:21-27.

3.PASCUAL MOSCARDO A (1998). Clinical investigation of the experimental fissure sealant K-0093 at the University of Valencia. Report to DENTSPLY.

4.PERLEA P, KOCH MJ , AIGUIER CH, PIOCH Th (1997). Beeinflussung der Fissurenversiegelung durch ein Schmelz-Dentin-Adhäsiv. Dtsch Zahnarztl Z 52 3. van Dijken JWV (1998). Clinical investigation of the experimental fissure sealant K-0093 at the University of Umeå. Report to DENTSPLY.

5.GUNGOR, HC; ALTAY, N; ALPAR, R Clinical evaluation of a polyacidmodified resin composite-based fissure sealant: Two-year results OPERATIVE DENTISTRY Volume: 29 Issue: 3 Pages: 254-260 Published: MAY-JUN 2004

6.CORNEA, D; SILAGHI-DUMITRESCU, L; BALAZSI, R; et al. The study of pit and fissure sealants concerning water sorption and solubility studia universitatis babes-bolyai chemia Volume: 61 Issue: 2 Pages: 239-248 Published: 2016

7.MATALON, S; PERETZ, B.; SIDON, R; et al. Antibacterial Properties of Pit and Fissure Sealants Combined With Daily Fluoride Mouth Rinse PEDIATRIC DENTISTRY Volume: 32 Issue: 1 Pages: 9-13 Published: JAN-FEB 2010

8.COURSON, F; RENDA, AM; Attal, JP; et al. In vitro evaluation of different techniques of enamel preparation for pit and fissure sealing JOURNAL OF ADHESIVE DENTISTRY Volume: 5 Issue: 4 Pages: 313-321 Published: WIN 2003

9.GHIORGHE, C.A., IOVAN, G., ANDRIAN, S., et al. Studies on Adhesion of Composite Resins and Glass-Ionomer Cements in Open-Sandwich Technique, Rev. Chim. (Bucharest), 68, no. 8, 2017, p. 1890-1894

10.HANGANU, S.C., ARMENCIA, A.O., MURARIU, A.M., MACOVEI, G., HANGANU, L.C., GRIGORAS, S., BOBU, L.I., In vitro Interaction Between Two Composite Restorative Materials and Artificial Saliva., Mat. Plast., 51, no. 4, 2014, p. 388-390.

11.STOLERIU, S.; IOVAN, G.; NICA, I; et al.The Effect of Heating on Surface Microhardness of Resin-based Materials for Direct Restoration, Mat. Plast., 55, no. 4, 2018, p. 584-589

12.BERESESCU, G., ORMENISAN, A., COMANEANU, R.,M., et al. FEM Analysis of Stress in Non-carious Cervical Lesion Restoration with Four Different Restorative Materials, Mat. Plast., 55, no. 1, 2018, p. 4245

13.HURJUI L.L., HURJUI I., MOSCU M., POPOVICI D. GRADINARU I. Update in relation between oral health and physiological changes in Pregnacy Romania J ournal Of Oral Rehabilitation Vol 9, Issue 4, pg.1824, oct-dec 2017

14.GRADINARU I., HURJUI L.L., HURJUI I., ANTOHE M.E. Romania J ournal Of Oral Rehabilitation Study on elevation of partially removable prostheses in systemic context in geriatric patients. Vol 10, Issue 4, pg.114-122, oct-dec 2018

15.GHIORGHE, C.A., GAMEN, A.C., TIRCA, T., et al. Laser Therapy Evaluation in Complications of Restorations by Total-Etch Technique Rev. Chim. (Bucharest), 69, no. 4, 2018, p. 921-925

Manuscript received: 15.02 .2019 